\title{
Toward a New Urban Cycle? A Closer Look to Sprawl, Demographic Transitions and the Environment in Europe
}

\author{
Daniela Smiraglia $^{1}$ (D) , Luca Salvati ${ }^{2, *}$, Gianluca Egidi ${ }^{3}$, Rosanna Salvia ${ }^{4}\left(\mathbb{D}\right.$, Antonio Giménez-Morera ${ }^{5}$ and \\ Rares Halbac-Cotoara-Zamfir ${ }^{6}$ (D)
}

1 Italian Institute for Environmental Protection and Research (ISPRA), Via Vitaliano Brancati 48, I-00144 Rome, Italy; daniela.smiraglia@isprambiente.it

2 Department of Economics and Law, University of Macerata, Via Armaroli 43, I-62100 Macerata, Italy

3 Department of Agricultural and Forestry Sciences (DAFNE), Tuscia University, Via San Camillo de Lellis, I-01100 Viterbo, Italy; egidi.gianluca@unitus.it

4 Department of Mathematics, Computer Science and Economics, University of Basilicata, Via dell'Ateneo Lucano 10, I-85100 Potenza, Italy; rosanna.salvia@unibas.it

5 Departamento de Economia y Ciencias Sociales, Universitat Politècnica de València, Cami de Vera S/N, ES-46022 València, Spain; angimo1@doctor.upv.es

6 Department of Overland Communication Ways, Foundation and Cadastral Survey, Politehnica University of Timisoara, 1A I. Curea Street, 300224 Timisoara, Romania; rares.halbac-cotoara-zamfir@upt.ro

* Correspondence: luca.salvati@unimc.it; Tel.: +39-06-61-57-10; Fax: +39-06-61-57-10-36

check for updates

Citation: Smiraglia, D.; Salvati, L.; Egidi, G.; Salvia, R.; Giménez-Morera, A.; Halbac-Cotoara-Zamfir, R. Toward a New Urban Cycle? A Closer Look to Sprawl, Demographic Transitions and the Environment in Europe. Land 2021, 10, 127.

https://doi.org/10.3390/land10020127

Academic Editor: Jefferey M. Sellers

Received: 27 December 2020

Accepted: 26 January 2021

Published: 28 January 2021

Publisher's Note: MDPI stays neutral with regard to jurisdictional claims in published maps and institutional affiliations.

Copyright: (c) 2021 by the authors. Licensee MDPI, Basel, Switzerland. This article is an open access article distributed under the terms and conditions of the Creative Commons Attribution (CC BY) license (https:/ / creativecommons.org/licenses/by/ $4.0 /)$.

\begin{abstract}
Urban growth is a largely debated issue in social science. Specific forms of metropolitan expansion-including sprawl-involve multiple and fascinating research dimensions, making mixed (quali-quantitative) analysis of this phenomenon particularly complex and challenging at the same time. Urban sprawl has attracting the attention of multidisciplinary studies defining nature, dynamics, and consequences that dispersed low-density settlements are having on biophysical and socioeconomic contexts worldwide. The present commentary provides a brief overview on nature and implications of the latent relationship between sprawl, demographic dynamics, and background socio-environmental contexts with special focus on Europe. Empirical evidence supports the idea that spatial planning should cope more effectively with the increasing environmental and socioeconomic exposure of European regions to sprawl and demographic transitions, being progressively far away from a traditional urban cycle with sequential waves of urbanization, suburbanization, counter-urbanization, and re-urbanization. Growing socio-ecological vulnerability of metropolitan regions was evaluated based on a literature review demonstrating how a better comprehension of the intimate linkage between long-term demographic dynamics and urban cycles is necessary to inform fine-tuned policies controlling sprawl and promoting a sustainable management of peri-urban land.
\end{abstract}

Keywords: metropolitan growth; local context; social dynamics; population trends; indicators; Europe

\section{Introduction}

Compactness and diffusion were (and still are) basic models of urban growth that have stimulated a vast debate regarding positive and negative externalities of these two urbanization patterns [1]. With increasing population, compact and dispersed patterns of urban expansion have become a matter of intense investigation [2,3]. In these regards, sprawl (low-density settlement expansion over larger regions) was becoming a more and more debated topic in the field of urbanism, planning, environmental sciences, ecology, economics, geography, and sociology [4-6]. The need for an accurate analysis of sprawl in the European context is becoming increasingly urgent for the formulation of efficient territorial policies [7]. As a complex, multi-dimensional phenomenon difficult to investigate [8], sprawl has attracting the interest of multi-disciplinary research when defining nature, dynamics, and implications of low-density urbanization on both fringe and rural environments [9-12]. Despite being one of the most powerful engine of urban growth, 
short-term population dynamics and long-term demographic change were occasionally investigated and contextualized to specific socioeconomic environments with a multidisciplinary perspective, e.g., offering an integrated ecological-economic view of urban sprawl [13-15].

Based on these premises, the present commentary focuses on sprawl dynamics at various spatial scales vis à vis population dynamics, in relation to environmental quality and land resource depletion [16]. More specifically, Chapter 2 recalls and comments some characteristic definitions of urban sprawl, outlining positive and negative socio-ecological implications in a broader perspective linking urban expansion, demographic trends and environmental quality. Definitions were discussed according with the typical spatial morphology and other features with which sprawl manifests itself-shedding specific light on the European continent $[17,18]$. Chapter 3 discusses the notion of 'demographic transition' with a specific reference to urban dynamics and metropolitan change. Chapter 4 outlines the intrinsic linkage between urban growth and demographic transitions in Europe, delineating in turn impacts and consequences of sprawl, in view of population and social dynamics, explored both qualitatively and quantitatively. We argued that such analysis has proved rather difficult when associated with a thorough evaluation of the effects of deteriorating fringe ecosystems, since the consumption of natural resources because of low-density urbanization is not easy to quantify [19], e.g., being strongly influenced by the socioeconomic profile of resident population [20].

Based on a literature review, Chapter 5 provides empirical findings linking urban sprawl, population trends, and environmental quality [21]. Through information provided by European Environment Agency, impacts of sprawl on peri-urban land have been quantified and contextualized over a sufficiently long timeframe [22]. Land consumption (mainly to the expense of cropland), as well as water consumption (the negative consequence of soil sealing on the recharge of groundwater basins), raw materials growing demand (especially for concrete), and energy consumption (mainly fossil fuels for transport) related to sprawl have been briefly discussed [23]. Assuming that, by extending urbanized areas over greater portions of land, the probability and frequency of disasters related to extreme weather events raise [24], our study has also commented briefly on the linkage between sprawl, population trends, and climate change. Chapter 6 generalizes the empirical findings of this study to wider social contexts in both affluent countries and emerging economies, arguing how the intrinsic mismatch between population growth and settlement expansionreflecting the shift from the first to the second demographic transition-is becoming a pervasive characteristic of the medium-term evolution of metropolitan systems all around the world.

\section{Toward a Comprehensive Definition of Sprawl?}

Seminal studies on sprawl have been carried out in North America [25,26], and nowadays sprawl is a major concern in both developed and emerging countries for its adverse socio-environmental impacts [27-30]. During the first part of the 20th century, sprawl in North America was mostly fuelled by the rapid increase of private car ownership and the preference for detached houses with gardens in peri-urban spaces [26,31]. Starting from this perspective, formal and informal definitions of sprawl have been (more or less intensively) investigated and discussed in mainstream literature [32]. The former definitions have focused on various features of sprawl, but at the same time they have evidenced the lack of a global and unique definition of this urban process [33,34]. Informal definitions have in turn contributed to provide evidence giving a better comprehension of exurban development case by case [35].

Vastly different definitions of sprawl were formulated under the assumption that this phenomenon varies over space [36]. Consequently, searching for a unique definition of sprawl is made even more difficult when different urbanization models across countries and regions are considered [3,37]. Traditionally, urban sprawl was defined as a low-density, inefficient settlement expansion [22,38-41]. This notion defines sprawl as a spatial pattern 
of urbanization associated with design features that encourage car dependency [42-45]. Nonetheless, other definitions of sprawl emphasize different characteristics of urban settlements, with both positive and negative connotations [46-49]. Neutral terms (such as 'urban deconcentration', 'suburban expansion', 'counter-urbanization') have not caught on, in part, because these terms do not suggest any distinction between sprawl and suburbanization [50-53]. While no consensus on the exact meaning of sprawl has been reached so far, scholars seem to agree on the key dimensions of this concept $[38,54,55]$. It seems clear that sprawl refers to a low-density development beyond the edge of a given city [56].

Recent definitions of sprawl suggest the importance of (re)thinking (and more precisely measuring) urban sprawl in terms of multiple indicators or functional dimensions rather than simply in terms of low-density settlement patterns [57]. Ewing and coworkers [58] suggest that sprawl might be regarded as a "process in which the spread of development across the landscape far outpaces population growth". In this sense, the definition given by Glaster and coworkers [59] is the one that best allows sprawl to be considered a process and not merely a spatial pattern of residential/service settlement. This process is initiated by social, economic, and environmental pressures that cause a fall in demand for land development in city centers while boosting it in peripheral areas [60]. Cities spread over a larger area, with building's volume remaining approximately constant [15]. This definition makes it possible to distinguish between (compact) growing processes of a given city with the spreading one [61]. Furthermore, the connection with the city allows distinguishing urban sprawling from urban sprinkling which widely affects the agricultural matrix upland or in interior plains [62-65]. This latter phenomenon is characterized by partially spontaneous development with a low level of control, difficult to manage because of the high energy costs, landscape, and ecosystems quality depletion, and technical-economic-organizational commitments burdensome in the provision of services of any kind [66].

\section{Demographic Transitions and Urban Sprawl}

Based on historical population trends of birth and death rates (the two variables shaping the natural balance of population), the first demographic transition was frequently used to delineate the long-term evolution of population through four sequential stages -usually reflecting important socioeconomic change at country and/or regional level [67]. Each stage is characterized by a specific relationship between demographic variables [68], with a cumulated impact on total population differing widely over time, as illustrated in Figure 1. Stage 1, typical of most of the world's countries before the Industrial Revolution, corresponded with very high birth and death rates, resulting in a fairly constant population size, with major swings corresponding with random events such as wars or pandemics. In Stage 2, economic development (directly or indirectly) contributed to lower death rates, with stably high birth rates determining a rapid population growth. In Stage 3, birth rates gradually decreased, as a result of improved socioeconomic conditions, an increase in women's status, and access to contraception. Population growth proceeded at a low/very low rate. Stage 4 corresponded to low birth and death rates and a stable population. A possible Stage 5 was finally proposed as typical of countries having stronger economies, higher levels of education, better healthcare, a higher proportion of working women, and a fertility rate systematically lower than the replacement rate, i.e., two children per woman [69-71].

In advanced economies, demographic dynamics in recent decades were not only explored following the assumptions of the Stage 5 of the 'first demographic transition' model. A 'second demographic transition' model was proposed since the late 1980s with the specific aim at interpreting more comprehensively the demographic dynamics typical of wealthier countries in which fertility rates have fallen significantly below replacement level ( 2 children per woman) and the elderly population is greater than the youthful population [72]. Following Lesthaeghe [73], the second demographic transition entails "sustained sub-replacement fertility, a multitude of living arrangements other than marriage, the disconnection between marriage and procreation, and no stationary population. 
The primary driver of these trends is the cultural shift toward postmodern attitudes and norms (i.e., those stressing individuality and self-actualization". At the individual level, this framework identifies value orientations as the principal determinant of fertility and family behavior, giving a coherent explanation of social trends toward individualized behaviors as far as different demographic processes are concerned, including-but not limited to-marriage and childbearing postponement, cohabitation, and living-apart-together patterns [70]. At the aggregate level, the second demographic transition may fruitfully delineate how actual (mostly 'urban') societies evolve over time, stressing the role of ideational change in the greater heterogeneity of local-scale population dynamics that affect urban growth-and mostly the expansion of low-density settlements-in a less predictable way than in the past [71]. From the metropolitan perspective, while compact urban growth has been frequently associated with Stages 3 and 4 of the first demographic transition-reflecting (more or less strong) population increases or demographic stability - sprawl is more typically linked with the rapid outward expansion of low-density cities in advanced economies $[51,59,74,75]$, mostly related with the early path of the second demographic transition [76].

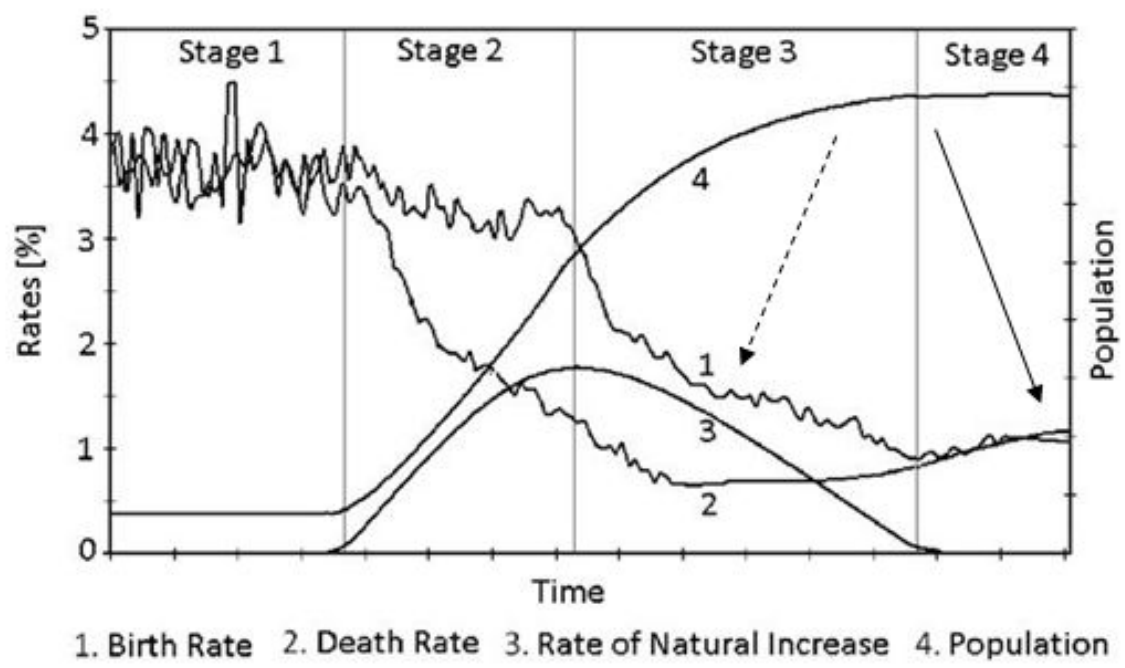

Figure 1. A simplified scheme illustrating the main phases of the first demographic transition in advanced economies and the possible emergence of compact growth (dashed arrow) and sprawl (continuous arrow) in such a framework (our elaboration).

\section{The Ignored Divide? An Outlook on Sprawl and Population Trends in Europe}

Urban dispersion became a common feature in the European cities, regardless of their geographical, economic, or administrative characteristics [77-79]. The rising interest on 'European forms' of urban sprawl is reflected in the increasing number of theoretical and empirical studies [75,80-82]. By the late 1980s, sprawl containment had become a major consideration of urban policy in most European countries. Based on both formal and informal definitions, the European Commission manifested its concerns for the diffusion of low-density settlements within the continent, as this was negatively contributing to the achievement of a sustainable development imposed by the United Nations [83]. Additionally, the European Commission highlighted the need for a more efficient land use in order to provide ecosystem functions and services for future generations [84].

Cities are often built on the most productive agricultural land, and unguided growth results in the unnecessary loss of fertile soils $[13,85]$. In these regards, the United Nations Agenda 21 asked all states to promote sustainable patterns of urban development and land use that should aim for compact growth. By the end of the 20th century, tackling sprawl was becoming a global affair [35]. Agenda 21 asked that all states promote sustainable patterns of land-use in order to contrast urban dispersion [31]. The European Commission also stated that "uncontrolled growth results in increased levels of private transport, 
increased energy consumption, makes infrastructures and services more costly and has negative effects on the quality of the countryside and the environment. (...) It is therefore necessary to work together to find sustainable solutions for planning and managing urban growth" [31]. In that period, the European Commission began to work on town planning strategies and socio-demographic policies that would consider mixed land-use and denser urban development as a tool to contain the impact of sprawl on both natural and social environments [86]. With this objective, the European Environment Agency argued that "the EU has specific obligations and a mandate to act and take a lead role in developing the right frameworks for intervention at all levels, and to pave the way for local action. Policies at all levels including local, national and European need to have an urban dimension to tackle urban sprawl and help to redress the market failures that drive urban sprawl. The provision of new visions for the spatial development of Europe's cities and regions is vital for the creation of a range of mutually reinforcing integrated policy responses" [31].

In many European countries, modern town planning was developed with the objective of controlling dispersed urban expansion, irrespective of the underlying population dynamics [15]. Additionally, urban planning fully accomplished its objective only partially, especially in its early stages [6]. In the aftermath of World War II, European countries invested heavily in planned urban expansion schemes based on stable demographic patterns and trends [2]. Based on a continuous expansion of settlements-associated with constant population increase in line with the assumptions of the first demographic transition -most of these schemes have stimulated peripheral expansion of existing urban areas with medium/low-density settlements [5]. Figure 2 illustrates the spatial outcome of recent processes of urbanization in Europe, evidencing the growth of urban areas across Europe from 1990 to 2000, a time interval reflecting the shift from compact to dispersed settlements in most of the European regions $[24,39,75]$.

This map highlights a substantial asymmetry between economically advanced regions of Western and Central Europe, where urbanization processes have been faster and oriented towards polycentric and spatially balanced development, and more peripheral districts of Southern and Eastern Europe, where the existing metropolitan systems appear more fragmented and grounded on a mono-centric (mostly compact) structure. This asymmetry reflects, on the European scale, the dualism between dynamic rural regions, with high accessibility and intermediate population density, and marginal locations with low accessibility and still oriented towards a traditional and low-density rural development. At the same time, the asymmetry reflects the inherent demographic gap between 'advanced' and 'marginal' European countries, the former moving from the 'first demographic transition' to the 'second demographic transition' earlier than the latter [71,73,76].

With the strong economic rise experienced by Western Europe, population growth increased significantly. Land urbanization was the inevitable consequence of a stronger economy and a bigger population with less predictable and more volatile trends, as far as fertility, life expectancy, and migration are concerned [87-89]. However, whilst North-West European cities reached their growing peak towards the middle of the 20th century, most conurbations of Southern and Eastern Europe followed growing trends until nearly the end of the last century. Based on these differential trends, Figure 3 highlights the spatial locations with the highest probability of land take in Europe. The rural areas with the greatest accessibility from the largest urban centers, with a flat position and intermediate population density, e.g., in Belgium, France, Germany, the Netherlands, and Northern Italy, were economically advanced, central locations most exposed to land take and moving more rapidly toward the second demographic transition at the end of the 20th century [68]. Although slowly expanding in more peripheral regions including the Scandinavian countries, and especially the Mediterranean Northern Arch and Eastern Europe, land-use transformations in such contexts are still limited to specific areas surrounding the largest cities and the most dynamic economic districts around urban areas [70]. 


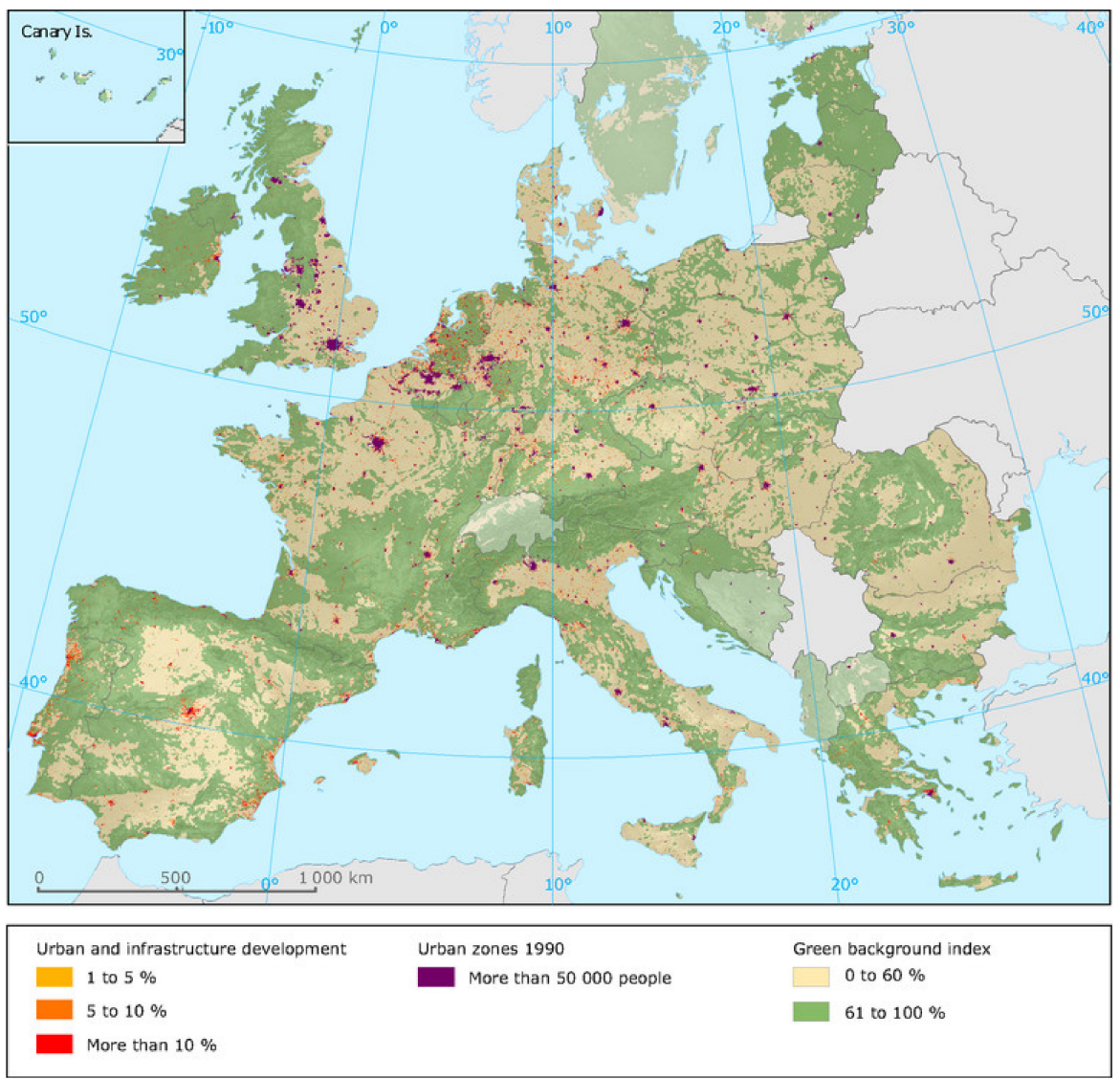

Figure 2. Urban zones in 1990 and urban development in 2000. Source: European Environment Agency [31].

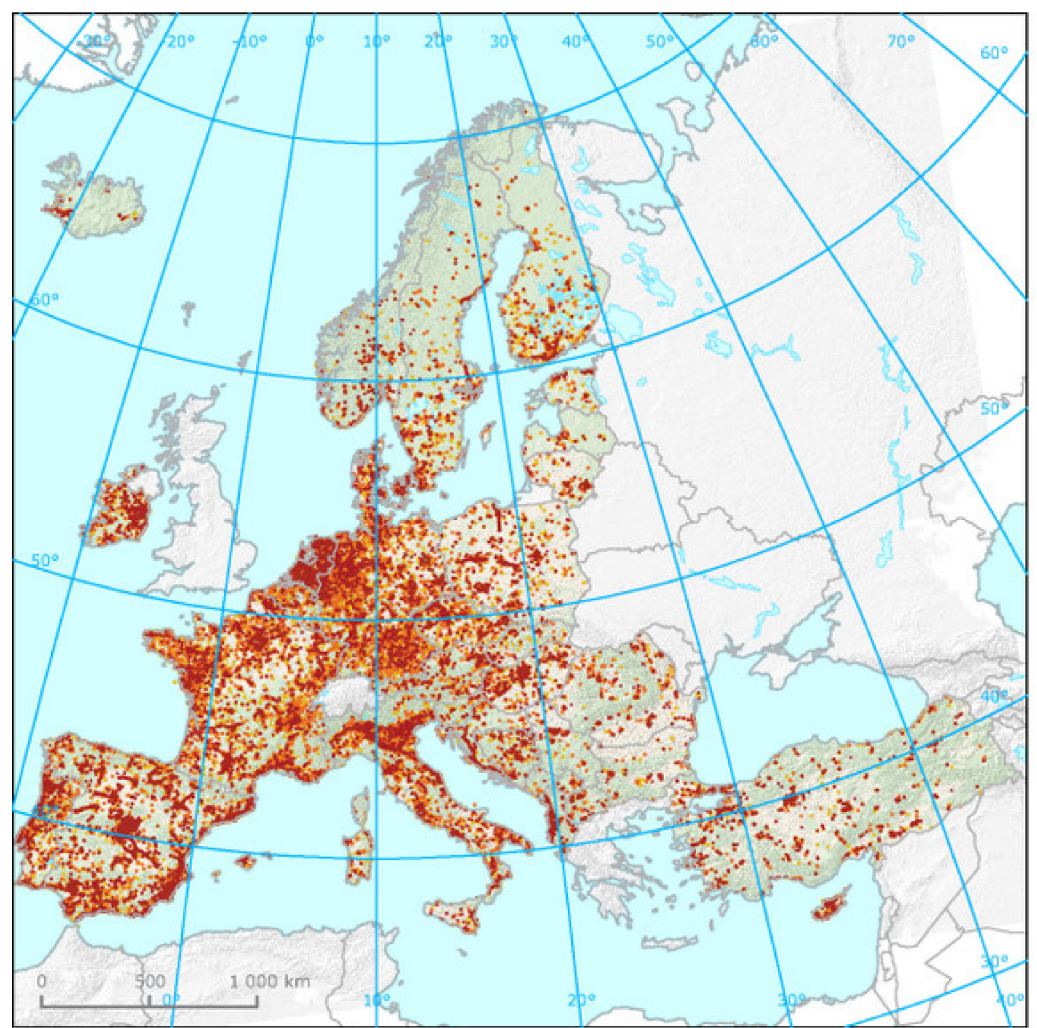

Figure 3. Land take intensity in Europe (2000-2018); darker tonalities indicate a higher probability of soil consumption (conversion to urban settlement) at the local scale. Source: https:/ / www.eea.europa.eu/data-and-maps/explore-interactivemaps/land-take-2000-2018. 
At the same time, changing industrial structures have also influenced processes of sprawl, and different trends can be observed in Europe that include (i) production shifts to other regions and countries; (ii) decentralization of employment to suburban locations; (iii) development of new forms of employment, especially in the service sector; and, finally, (iv) shrinkage and closure of traditional industries. The latter process had the effect of removing employment and weakening the latent linkage between inner urban residential and workplaces areas, stimulating the outward migration of workers to suburban areas $[1,14,32,35]$.

Being quite distinctive from past conditions, demographic forecasts suggest that European urban population will increase only moderately because of ageing and low fertility, being increasingly dependent on inward migration from countries outside the continent and the intrinsic heterogeneity of individual behaviors as far as fertility decline, non-standard forms of marriage and cohabitation, and childbearing postponement are concerned $[67,69]$. However, migration flows from East to West, from South to North, and from rural to urban areas-considered to be a general and spatially consistent trend over the last half a century-determine a still relevant contribution to metropolitan expansion in Europe. As a matter of fact, European population living in urban areas is predicted to rise from $73 \%$ to $78 \%$ between 2005 and 2025 [90], meaning that urban areas will have to provide housing for an additional 28 million inhabitants over this time period. Competition for capital attraction amongst cities has reinforced this process [1].

At the same time, by comparing the growth of population with the increase of builtup areas in selected cities, the European Environment Agency [31] argued that built-up areas grew at a higher pace than population, concluding that "over the past 20 years low density suburban development in the periphery of Europe's cities has become the norm, and the expansion of urban areas in many Eastern and Western European countries has increased by over three times the growth of population". Socio-demographic change was demonstrated to be at the base of such processes, encouraging 'suburban' ways of life needing more space, e.g., determining an increased demand for detached houses with gardens, swimming pools, and parking lots and thus intrinsically alimenting lowdensity urban growth. Interestingly, expansion of spatially discontinuous, medium-low density residential settlements was observed in both advanced and economically dynamic contexts with stable (or slightly increasing) population and in marginal, peripheral, and mostly economically disadvantaged districts with slightly (or more intensively) declining population. While the socioeconomic mechanisms underlying urban sprawl in a context of growing population are rather clear and well documented in Europe, additional research is needed to clarify the linkage between demographic shrinkage and urban sprawl, especially in peripheral countries and regions.

Earlier studies have demonstrated how formation and consolidation of spatial mismatches between settlement expansion and population growth are associated with the latent shift from population dynamics mainly governed by the assumptions typical of the first demographic transition (high fertility, low mortality, traditional families, stable immigration rates) to more complex dynamics reflecting the second demographic transition (low fertility, increasing life expectancy, non-conventional families and households, highly volatile migration rates, individual heterogeneity in demographic behaviors) $[70,73,76]$. By reflecting an increased land take, Figure 4 plastically illustrated this process all over Europe, evidencing how the largest proportion of cities in the continent-irrespective of the macro-region or country they belong to-was experiencing a higher increase in settlement area than population growth rate. The largest concentration of cities with built-up area expansion higher than population growth (red dots) was found in a large part of Western and Central Europe moving from France to Poland. The reverse pattern (green dots) was more dispersed in the continent, being randomly observed in cities of Spain, Southern France, Switzerland, Northern Italy, and Hungary. However, a weak differentiation from Northern to Southern Europe can be envisaged from the map (more green dots toward the South), in turn documenting how per-capita built-up area is substantially higher in West- 
ern/Northern/Central European cities. Systematically lower values of per-capita built-up area partly reflect the 'compact settlement' tradition typical of the post-war (tumultuous) urban development in Mediterranean countries.

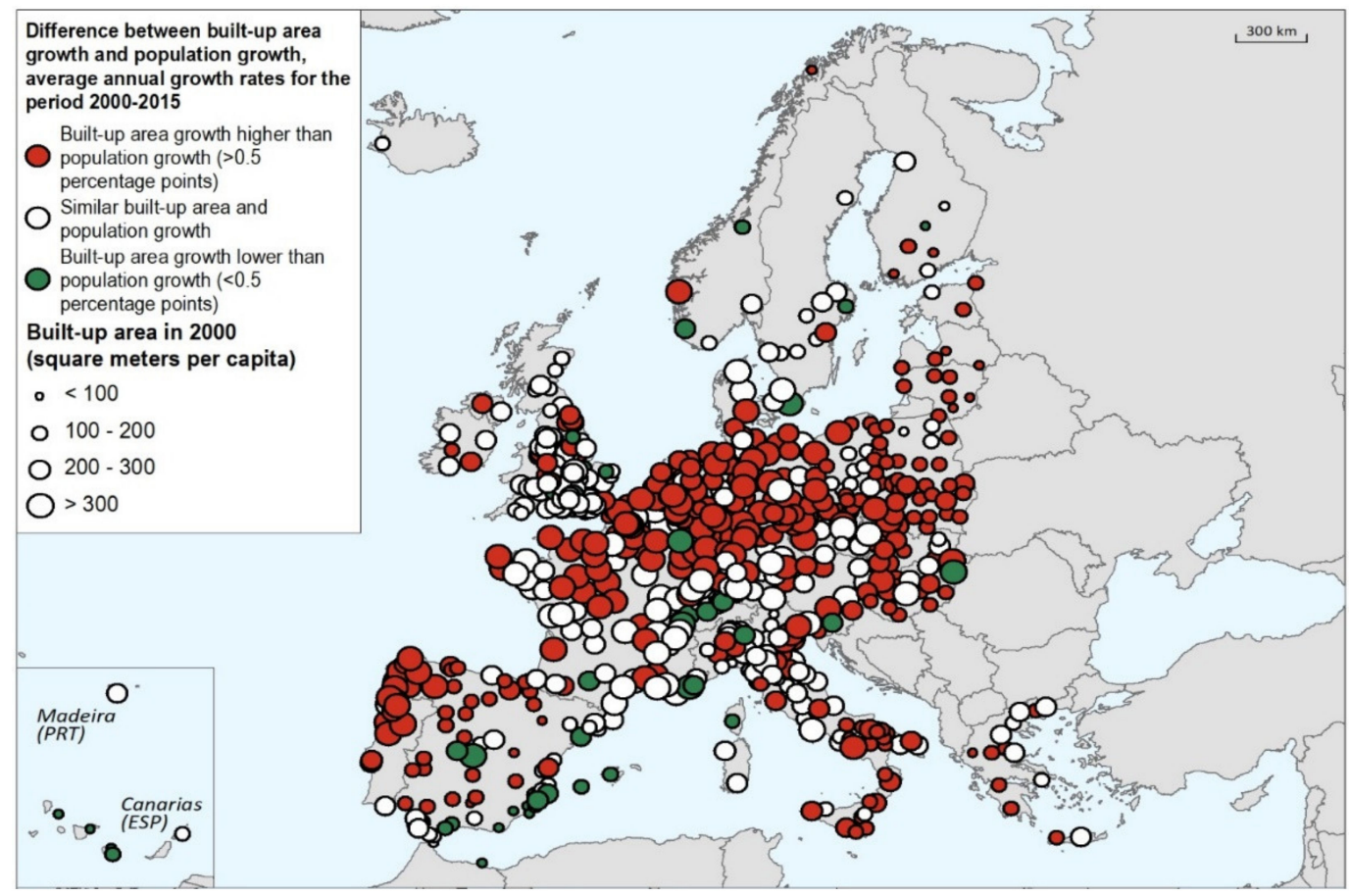

Figure 4. Difference between built-up area growth and population growth, 2000-2015 in selected European cities. Source: OECD.

\section{Environmental Quality, Sprawl and Population Dynamics}

Following - and sometimes reflecting - the transition from the first to the second demographic transition in Europe, the most recent low-density developmental patterns have demonstrated to exert socio-ecological costs and implications on non-urban environments [1]. Most of these concern the deterioration of natural ecosystems and landscapes, besides direct financial costs [32]. Sprawl not only results in direct habitat loss, but also has a considerable impact on natural resources at large [59], causing the loss of various ecosystem services [91]. When compared with a compact development pattern, a generalized consequence of low-density suburban growth is greater resource consumption leading to environmental degradation and soil loss [16]. This may also depend on the different social attitudes and behaviors of households living in compact and dispersed settlements, with the latter usually having a high ecological footprint [35].

Low-density suburban development not only degrades environmental resources such as water quality, air quality, and wildlife habitats [45], but also limits or eliminates accessibility to natural resources such as agricultural land, timberland, minerals, and water [92-94]. One of the biggest problems is related with the alteration of regulation services [95], especially those linked with soil, since sprawl-driven soil losses lead to changes in the water drainage (with an increasing flood risk), groundwater level, and local micro-climate regimes because of the heat island effect [96-99]. Table 1 provides an overview of land consumption processes in Europe since 2000, considering three time intervals of six years each. The highest land take rate was found associated with agricultural areas and pastures. Forests and wetlands were the land use less affected by urban sprawl, being likely more protected throughout Europe in the surroundings of urban areas. In most cases, they were extensively included in natural reserves, protected areas, and green infrastructures for their intrinsic biodiversity value. Despite an undiscussed ecological 
value, natural grassland and schlerophyllous vegetation underwent (more or less) intense conversion to urban uses. Although land take rates tend to decrease over time, they still appear quite strong in the last time interval as regards cultivated fields (arable land and permanent crops) and pastures [100-103].

Table 1. Land take (per cent share in total landscape) by land use type in Europe. Source: https: / / www.eea.europa.eu/data-and-maps/indicators/land-take-3/assessment.

\begin{tabular}{cccccc}
\hline $\begin{array}{c}\text { Time } \\
\text { Interval }\end{array}$ & $\begin{array}{c}\text { Arable Land } \\
\text { and } \\
\text { Permanent } \\
\text { Crops }\end{array}$ & $\begin{array}{c}\text { Forests and } \\
\text { Transitional } \\
\text { WoodLand } \\
\text { Shrub }\end{array}$ & $\begin{array}{c}\text { Natural } \\
\text { Grassland, } \\
\text { Sclerophylous } \\
\text { Vegetation }\end{array}$ & $\begin{array}{c}\text { Pastures and } \\
\text { Mosaic } \\
\text { Farmland }\end{array}$ & Wetland \\
\hline $2000-2006$ & 0.24 & 0.05 & 0.15 & 0.23 & 0.02 \\
$2006-2012$ & 0.22 & 0.05 & 0.11 & 0.17 & 0.03 \\
$2012-2018$ & 0.13 & 0.03 & 0.05 & 0.11 & 0.04 \\
$2000-2018$ & 0.58 & 0.13 & 0.30 & 0.49 & 0.08 \\
\hline
\end{tabular}

Going beyond the specific issue of land consumption, a comparison of environmental targets between compact (high-density) and dispersed (low-density) patterns of urbanization may identify additional (negative) impacts of sprawl on peri-urban areas. Such analysis may benefit from a sociological assessment considering the contribution of different population segments settling in the two types of settlements. According to Kahn [16], the environmental costs of suburbanization (e.g., more associated with low-density settlements) are a function of how much extra resources new households and inhabitants of suburbia consume [42-44,104]. These resources are mainly fossil fuels (related to home energy consumption and the increasing vehicle mileage) and rural-agricultural land [105-108]. Newman and Kenworthy [108] outlined a positive relationship between low-density urban development and per-capita energy (and water) consumption. Empirical findings indicate that urban sprawl leads to higher consumptions of fossil fuels and natural resources [109-112], stimulating in turn a higher demand for raw materials typically produced in remote locations and requiring transportation [113-115]. This increased demand reflects major expansion of construction activity, mainly along the sea coast and around major cities [116]. Associated environmental conflicts include the expansion of quarries adjacent to nature reserves and the over-extraction of gravel from river beds. Sprawl has been sometimes associated with higher levels of air pollution because of the massive use of private car as the most feasible transportation mode in low-density districts with less effective connections with public transport. Based on these premises, sprawl definitely poses significant threats to the Paris Agreement commitments to reduce greenhouse gas emissions [117], acting antithetically to compact urban growth. The latter expansion mode was associated to a higher demand of public transportation, lower levels of per-capita energy and water consumption, lower demand for raw materials.

\section{Concluding Remarks}

Our study demonstrates the inherent complexity of the socioeconomic phenomena underlying sprawl dynamics and (more or less) uncontrolled expansion of metropolitan areas. These phenomena require increasingly integrated approaches assessing the intrinsic loss of natural resources (e.g., water, soil, air) in both physical and monetary terms vis à vis the inherent demographic change at the base of such transformations. Environmental accounting approaches capable of linking land-use changes in socially diversified peri-urban areas with the main aspects of environmental degradation and with regional economic transformations are particularly appreciated in this direction of research. At the same time, the linkage between urban sprawl, population dynamics, and non-demographic drivers of settlement expansion requires a deeper investigation based on comparative studies.

Exploratory and interpretative approaches are especially necessary to analyzing —with sufficient theoretical depth and empirical breadth - the intimate relationships between 
environmental degradation at metropolitan fringe and social phenomena such as ethnic and class segregation, social filtering, and gentrification, regarded as latent engines of sprawl. The progressive mismatch between the growth of urbanized areas and the increase in the resident population is the most evident result of this interaction, whose optimal regulation requires a continuous update of planning tools and local development policies at the most appropriate spatial scale.

Based on the empirical findings of this study-focusing on Europe but being generalizable to other social contexts in both affluent countries and emerging economies - the apparent mismatch between population growth and settlement expansion is demonstrated to be a particularly diffused characteristic of urban system's evolution worldwide. Policies containing land consumption in conditions of stable or decreasing population (e.g., urban shrinkage) seem to be effective only in few cases, frequently determining negative socio-ecological consequences for fringe environments. Finely tuned policies mitigating land take rates in metropolitan regions require a more advanced knowledge of the intrinsic drivers of urban change, specific monitoring approaches, and planning rules adapting to largely transformative peri-urban environments.

Author Contributions: Conceptualization, L.S. and R.S.; methodology, D.S.; software, G.E.; validation, D.S. and R.H.-C.-Z.; formal analysis, A.G.-M.; investigation, L.S.; resources, A.G.-M.; data curation, R.S.; writing—original draft preparation, D.S. and L.S.; writing-review and editing, G.E. and R.H.-C.-Z.; visualization, R.S.; supervision, G.E.; project administration, D.S.; funding acquisition, D.S. All authors have read and agreed to the published version of the manuscript.

Funding: This research received no external funding.

Institutional Review Board Statement: Not applicable.

Informed Consent Statement: Informed consent was obtained from all subjects involved in the study.

Data Availability Statement: No new data were created or analyzed in this study. Data sharing is not applicable to this article.

Conflicts of Interest: The authors declare no conflict of interest.

\section{References}

1. Wang, X.; Shi, R.; Zhou, Y. Dynamics of urban sprawl and sustainable development in China. Socio-Econ. Plan. Sci. 2020, 70, 100736. [CrossRef]

2. Bruegmann, R. Sprawl: A Compact History; University of Chicago Press: Chicago, IL, USA, 2005.

3. Schneider, A.; Woodcock, C.E. Compact, dispersed, fragmented, extensive? A comparison of urban growth in 25 global cities using remotely sensed data, pattern metrics and census information. Urban Stud. 2008, 45, 659-692. [CrossRef]

4. Chorianopoulos, I.; Pagonis, T.; Koukoulas, S.; Drymoniti, S. Planning, competitiveness and sprawl in the Mediterranean city: The case of Athens. Cities 2010, 27, 249-259. [CrossRef]

5. Nijkamp, P.; Kourtit, K. The "new urban Europe": Global challenges and local responses in the urban century. Eur. Plan. Stud. 2013, 21, 291-315. [CrossRef]

6. Zambon, I.; Serra, P.; Sauri, D.; Carlucci, M.; Salvati, L. Beyond the 'Mediterranean city': Socioeconomic disparities and urban sprawl in three Southern European cities. Geogr. Ann. Ser. B 2017, 99, 319-337. [CrossRef]

7. Prud'homme, R.; Lee, G. Sprawl, Speed and the Efficiency of Cities. Urban Stud. 1999, 36, 1849-1858. [CrossRef]

8. Davoudi, S. Polycentricity in European Spatial Planning: From an Analytical Tool to a Normative Agenda. Eur. Plan. Stud. 2003, 11, 979-999. [CrossRef]

9. Chin, N. Unearthing the Roots of Urban Sprawl: A Critical Analysis of Form, Function and Methodology; Series 47; Centre for Advanced Spatial Analysis: London, UK, 2002.

10. Hasse, J.E. A Geospatial Approach to Measuring New Development for Characteristics of Sprawl. Landsc. J. 2004, $23,52-67$. [CrossRef]

11. Xiaojun, Y. Urban Remote Sensing: Monitoring, Synthesis and Modeling in the Urban Environment; Wiley: Chichester, UK, 2011.

12. Colantoni, A.; Grigoriadis, E.; Sateriano, A.; Venanzoni, G.; Salvati, L. Cities as selective land predators? A lesson on urban growth, deregulated planning and sprawl containment. Sci. Total Environ. 2016, 545, 329-339. [CrossRef]

13. Bhat, P.A.; Shafiq, M.U.; Mir, A.A.; Ahmed, P. Urban sprawl and its impact on land use/land cover dynamics of Dehradun City, India. Int. J. Sustain. Built Environ. 2017, 6, 513-521. [CrossRef]

14. Marais, L.; Denoon-Stevens, S.; Cloete, J. Mining towns and urban sprawl in South Africa. Land Use Policy 2020, $93,103953$. [CrossRef] 
15. Salvati, L.; Ciommi, M.T.; Serra, P.; Chelli, F.M. Exploring the spatial structure of housing prices under economic expansion and stagnation: The role of socio-demographic factors in metropolitan Rome, Italy. Land Use Policy 2019, 81, 143-152. [CrossRef]

16. Kahn, M.E. The environmental impact of suburbanization. J. Policy Anal. Manag. 2000, 19, 569-586. [CrossRef]

17. Hall, P. The Future of Metropolis and Its Form. Reg. Stud. 1997, 31, 211-220. [CrossRef]

18. Jaret, C.; Ghadge, R.; Reid, L.W.; Adelman, R.M. The Measurement of Suburban Sprawl: An Evaluation. City Community 2009, 8, 65-84. [CrossRef]

19. Craglia, M.; Leontidou, L.; Nuvolati, G.; Schweikart, J. Towards the Development of Quality Indicators in the 'Digital' City. Environ. Plan. B Urban Anal. City Sci. 2004, 31, 51-64. [CrossRef]

20. Frenkel, A.; Ashkenazi, M. Measuring Urban Sprawl: How can We Deal with It? Environ. Plan. B Urban Anal. City Sci. 2008, 35, 56-79. [CrossRef]

21. Hasse, J.E.; Lathrop, R.G. Land Resource Impact Indicators of Urban Sprawl. Appl. Geogr. 2003, 23, 159-175. [CrossRef]

22. Salvati, L.; Zambon, I.; Chelli, F.M.; Serra, P. Do spatial patterns of urbanization and land consumption reflect different socioeconomic contexts in Europe? Sci. Total Environ. 2018, 625, 722-730. [CrossRef]

23. Haase, D.; Nuissl, H. The urban-to-rural gradient of land use change and impervious cover: A long-term trajectory for the city of Leipzig. Land Use Sci. 2010, 5, 123-142. [CrossRef]

24. Díaz-Pacheco, J.; García-Palomares, J.C. Urban sprawl in the Mediterranean urban regions in Europe and the crisis effect on the urban land development: Madrid as study case. Urban Stud. Res. 2014, 2014, 807381. [CrossRef]

25. Downs, A. Some Realities about Sprawl and Urban Decline. Hous. Policy Debate 1999, 10, 955-974. [CrossRef]

26. Richardson, H.W.; Chang-Hee, C.B. Urban Sprawl in Western Europe and the United States; Ashgate: London, UK, 2004.

27. Frenkel, A.; Ashkenazi, M. The integrated sprawl index: Measuring the urban landscape in Israel. Ann. Reg. Sci. 2007, 42, 99-121. [CrossRef]

28. Arribas-Bel, D.; Nijkamp, P.; Scholten, H. Multidimensional urban sprawl in Europe: A self-organizing map approach. Comput. Environ. Urban Syst. 2011, 35, 263-275. [CrossRef]

29. Morote, Á.F.; Hernández, M. Urban sprawl and its effects on water demand: A case study of Alicante, Spain. Land Use Policy 2016, 50, 352-362. [CrossRef]

30. Johnson, M.P. Environmental Impacts of Urban Sprawl: A Survey of the Literature and Proposed Research Agenda. Environ. Plan. A 2001, 33, 717-735. [CrossRef]

31. European Environment Agency. Urban Sprawl in Europe-The Ignored Challenge; EEA Report No. 10; European Environment Agency: Copenhagen, Denmark, 2006.

32. Tian, L.; Li, Y.; Yan, Y.; Wang, B. Measuring urban sprawl and exploring the role planning plays: A Shanghai case study. Land Use Policy 2017, 67, 426-435. [CrossRef]

33. Tsai, Y. Quantifying Urban Form: Compactness versus Sprawl. Urban Stud. 2005, 42, 141-161. [CrossRef]

34. Newman, P.; Thornley, A. Urban Planning in Europe—International Competition, National Systems and Planning Projects; Routledge: London, UK, 1996.

35. Sahana, M.; Hong, H.; Sajjad, H. Analyzing urban spatial patterns and trend of urban growth using urban sprawl matrix: A study on Kolkata urban agglomeration, India. Sci. Total Environ. 2018, 628, 1557-1566. [CrossRef]

36. Veneri, P.; Burgalassi, D. Questioning polycentric development and its effects. Issues of definition and measurement for the Italian NUTS-2 regions. Eur. Plan. Stud. 2012, 20, 1017-1037. [CrossRef]

37. Longhi, C.; Musolesi, A. European cities in the process of economic integration: Towards structural convergence. Ann. Reg. Sci. 2007, 41, 333-351. [CrossRef]

38. Salvati, L.; Carlucci, M. Patterns of sprawl: The socioeconomic and territorial profile of dispersed urban areas in Italy. Reg. Stud. 2016, 50, 1346-1359. [CrossRef]

39. Salvati, L.; Ferrara, A.; Chelli, F. Long-term growth and metropolitan spatial structures: An analysis of factors influencing urban patch size under different economic cycles. Geogr. Tidsskr. 2018, 118, 56-71. [CrossRef]

40. Salvati, L.; Carlucci, M.; Grigoriadis, E.; Chelli, F.M. Uneven dispersion or adaptive polycentrism? Urban expansion, population dynamics and employment growth in an 'ordinary' city. Rev. Reg. Res. 2018, 38, 1-25. [CrossRef]

41. Zambon, I.; Rontos, K.; Serra, P.; Colantoni, A.; Salvati, L. Population Dynamics in Southern Europe: A Local-Scale Analysis, 1961-2011. Sustainability 2019, 11, 109. [CrossRef]

42. Chelli, F.; Rosti, L. Age and gender differences in Italian workers' mobility. Int. J. Manpow. 2002, 23, 313-325. [CrossRef]

43. Rosti, L.; Chelli, F. Self-employment among Italian female graduates. Educ. Train. 2009, 51, 526-540. [CrossRef]

44. Rosti, L.; Chelli, F. Higher education in non-standard wage contracts. Educ. Train. 2012, 54, 142-151. [CrossRef]

45. Koprowska, K.; Łaszkiewicz, E.; Kronenberg, J. Is urban sprawl linked to green space availability? Ecol. Indic. 2020, 108, 105723. [CrossRef]

46. Bullard, R.D.; Glenn, S.J.; Torres, A.O. Sprawl City; Island Press: Washington, DC, USA, 2000.

47. Peiser, R. Decomposing urban sprawl. Town Plan. Rev. 2001, 3, 96-108. [CrossRef]

48. Squires, G.D. Urban Sprawl: Causes, Consequences, and Policy Decisions; Urban Institute Press: Washington, DC, USA, 2002.

49. Castagnetti, C.; Chelli, F.; Rosti, L. Educational performance as signalling device: Evidence from Italy. Econ. Bull. $2005,9,1-7$.

50. Vaz, E.; Nijkamp, P. Gravitational forces in the spatial impacts of urban sprawl: An investigation of the region of Veneto, Italy. Habitat Int. 2015, 45, 99-105. [CrossRef] 
51. Salvati, L.; Serra, P. Estimating Rapidity of Change in Complex Urban Systems: A Multidimensional, Local-Scale Approach. Geogr. Anal. 2016, 48, 132-156. [CrossRef]

52. Carlucci, M.; Chelli, F.M.; Salvati, L. Toward a new cycle: Short-term population dynamics, gentrification, and re-urbanization of Milan (Italy). Sustainability 2018, 10, 3014. [CrossRef]

53. Ciommi, M.; Chelli, F.M.; Salvati, L. Integrating parametric and non-parametric multivariate analysis of urban growth and commuting patterns in a European metropolitan area. Qual. Quant. 2019, 53, 957-979. [CrossRef]

54. Gigliarano, C.; Chelli, F.M. Measuring inter-temporal intragenerational mobility: An application to the Italian labour market. Qual. Quant. 2016, 50, 89-102. [CrossRef]

55. Ciommi, M.; Chelli, F.M.; Carlucci, M.; Salvati, L. Urban growth and demographic dynamics in southern Europe: Toward a new statistical approach to regional science. Sustainability 2018, 10, 2765. [CrossRef]

56. Downs, A. The Challenge of Our Declining Big Cities. Hous. Policy Debate 1997, 8, 359-408. [CrossRef]

57. Salvati, L.; Gargiulo Morelli, V. Unveiling Urban Sprawl in the Mediterranean Region: Towards a Latent Urban Transformation? Int. J. Urban Reg. Res. 2014, 38, 1935-1953. [CrossRef]

58. Ewing, R.; Pendall, R.; Chen, D. Measuring Sprawl and Its Impact; Smart Growth America: Washington, DC, USA, 2002.

59. Galster, G.; Hanson, R.; Ratcliffe, M.R.; Wolman, H.; Coleman, S.; Freihage, J. Wrestling Sprawl to the Ground: Defining and Measuring an Elusive Concept. Hous. Policy Debate 2001, 12, 681-717. [CrossRef]

60. Salvati, L.; Guandalini, A.; Carlucci, M.; Chelli, F.M. An empirical assessment of human development through remote sensing: Evidences from Italy. Ecol. Indic. 2017, 78, 167-172. [CrossRef]

61. Rauhut, D. Polycentricity-one concept or many? Eur. Plan. Stud. 2017, 25, 332-348. [CrossRef]

62. Romano, B.; Zullo, F. Half a century of urbanisation in Southern European lowlands a study on the Po Valley (Northern Italy). Urban Res. Pract. 2016, 9, 109-130. [CrossRef]

63. Ciommi, M.; Gentili, A.; Ermini, B.; Chelli, F.M.; Gallegati, M. Have Your Cake and Eat it Too: The Well-Being of the Italians (1861-2011). Soc. Indic. Res. 2017, 134, 473-509. [CrossRef]

64. Ciommi, M.; Gigliarano, C.; Emili, A.; Taralli, S.; Chelli, F.M. A new class of composite indicators for measuring well-being at the local level: An application to the Equitable and Sustainable Well-being (BES) of the Italian Provinces. Ecol. Indic. 2017, 76, 281-296. [CrossRef]

65. Romano, B.; Zullo, F.; Fiorini, L.; Marucci, A.; Ciabò, S. Land transformation of Italy due to half a century of urbanization. Land Use Policy 2017, 67, 387-400. [CrossRef]

66. Hennig, E.I.; Soukup, C.S.T.; Orlitová, E.; Kienast, F.; Jaeger, J.A.G. Multi-scale analysis of urban sprawl in Europe: Towards a European de-sprawling strategy. Land Use Policy 2015, 49, 483-498. [CrossRef]

67. Lesthaeghe, R.; Neels, K. From the first to the second demographic transition: An interpretation of the spatial continuity of demographic innovation in France, Belgium and Switzerland. Eur. J. Popul. 2002, 18, 325-360. [CrossRef]

68. Lee, R.D.; Reher, D.S. Introduction: The landscape of demographic transition and its aftermath. Popul. Dev. Rev. 2011, 37, 1-7. [CrossRef]

69. Kirk, D. Demographic transition theory. Popul. Stud. 1996, 50, 361-387. [CrossRef]

70. Lee, R.; Mason, A. Fertility, human capital, and economic growth over the demographic transition. Eur. J. Popul. 2010, 26, 159-182. [CrossRef] [PubMed]

71. Zaidi, B.; Morgan, S.P. The second demographic transition theory: A review and appraisal. Annu. Rev. Sociol. 2017, 43, 473-492. [CrossRef] [PubMed]

72. Lesthaeghe, R. The second demographic transition: A concise overview of its development. Proc. Natl. Acad. Sci. USA 2014, 111, 18112-18115. [CrossRef] [PubMed]

73. Lesthaeghe, R. The unfolding story of the second demographic transition. Popul. Dev. Rev. 2010, 36, 211-251. [CrossRef] [PubMed]

74. Ewing, R. Is Los Angeles-style sprawl desirable? J. Am. Plann. Assoc. 1997, 63, 107-126. [CrossRef]

75. Di Feliciantonio, C.; Salvati, L. 'Southern' Alternatives of Urban Diffusion: Investigating Settlement Characteristics and SocioEconomic Patterns in Three Mediterranean Regions. Tijdschr. Econ. Soc. Geogr. 2015, 106, 453-470. [CrossRef]

76. Kasanko, M.; Barredo, J.I.; Lavalle, C.; McCormick, N.; Demicheli, L.; Sagris, V.; Brezger, A. Are European cities becoming dispersed? A comparative analysis of 15 European urban areas. Landsc. Urban Plan. 2006, 77, 111-130. [CrossRef]

77. Salvati, L.; De Rosa, S. 'Hidden Polycentrism' or 'Subtle Dispersion'? Urban growth and long-term sub-centre dynamics in three Mediterranean cities. Land Use Policy 2014, 39, 233-243. [CrossRef]

78. Strollo, A.; Smiraglia, D.; Bruno, R.; Assennato, F.; Congedo, L.; De Fioravante, P.; Giuliani, C.; Marinosci, I.; Riitano, N.; Munafò, M. Land consumption in Italy. J. Maps 2020, 16, 113-123. [CrossRef]

79. Couch, C.; Leontidou, L.; Petschel-Held, G. Urban Sprawl in Europe—Landscapes, Land-Use Change E Policy; Blackwell Publishing: Oxford, UK, 2007.

80. Smiraglia, D.; Rinaldo, S.; Ceccarelli, T.; Bajocco, S.; Salvati, L.; Ricotta, C.; Perini, L. A cost-effective approach for improving the quality of soil sealing change detection from landsat imagery. Eur. J. Remote Sens. 2014, 47, 805-819. [CrossRef]

81. Moroni, S.; Minola, L. Unnatural sprawl: Reconsidering public responsibility for suburban development in Italy, and the desirability and possibility of changing the rules of the game. Land Use Policy 2019, 86, 104-112. [CrossRef]

82. United Nations, Department of Economic and Social Affairs, Population Division. World Urbanization Prospects: The 2018 Revision; (ST/ESA/SER.A/420); United Nations: New York, NY, USA, 2019. 
83. European Commission. No Net Land Take by 2050? Science for Environment Policy; Future Brief 14, Produced for the European Commission DG Environment by the Science Communication Unit; UWE: Bristol, UK, 2016; Available online: https:/ / ec.europa. eu/environment/integration/research/newsalert/future_briefs.htm (accessed on 26 January 2021).

84. Shalaby, A.; Moghanm, F.S. Assessment of urban sprawl on agricultural soil of northern Nile Delta of Egypt using RS and GIS. Chin. Geogr. Sci. 2015, 25, 274-282. [CrossRef]

85. European Commission. Guidelines on Best Practice to Limit, Mitigate or Compensate Soil Sealing; European Commission: Bruxelles, Belgium, 2012; Available online: https: / / www.eea.europa.eu/policy-documents / guidelines-on-best-practice-to (accessed on 26 January 2021).

86. Chelli, F.; Gigliarano, C.; Mattioli, E. The impact of inflation on heterogeneous groups of households: An application to Ialy. Econ. Bull. 2009, 29, 1276-1295.

87. Lamonica, G.R.; Chelli, F.M. The performance of non-survey techniques for constructing sub-territorial input-output tables. Pap. Reg. Sci. 2018, 97, 1169-1202. [CrossRef]

88. Getzner, M.; Kadi, J. Determinants of land consumption in Austria and the effects of spatial planning regulations. Eur. Plan. Stud. 2020, 28, 1095-1117. [CrossRef]

89. Caragliu, A.; Del Bo, C.; Nijkamp, P. Smart cities in Europe. J. Urban Technol. 2011, 18, 65-82. [CrossRef]

90. United Nations. World Urbanization Prospects: The 2006 Revision; United Nations: New York, NY, USA, 2007.

91. Haines-Young, R.H.; Potschin-Young, M.B. Common International Classification of Ecosystem Services (CICES) V5.1 and Guidance on the Application of the Revised Structure. 2018. Available online: www.cices.eu (accessed on 27 December 2020).

92. Collinge, S.K. Ecological consequences of habitat fragmentation: Implications for landscape architecture and planning. Landsc. Urban Plan. 1996, 36, 59-77. [CrossRef]

93. Bennett, A.F.D.; Saunders, A. Habitat fragmentation and landscape change. In Conservation Biology for All; Sodhi, N.S., Ehrlich, P.R., Eds.; Oxford University Press: Oxford, UK, 2010. [CrossRef]

94. Gounaridis, D.; Newell, J.P.; Goodspeed, R. The impact of urban sprawl on forest landscapes in Southeast Michigan, 1985-2015. Landsc. Ecol. 2020, 35, 1975-1993. [CrossRef]

95. Haines-Young, R.H.; Potschin-Young, M.B. The links between biodiversity, ecosystem services and human well-being. In Ecosystem Ecology: A New Synthesis; Raffaelli, D.G., Frid, C.L.J., Eds.; Cambridge University Press: Cambridge, UK, 2010; pp. 110-139. [CrossRef]

96. Lauf, S.; Haase, D.; Kleinschmit, B. Linkages between ecosystem services provisioning, urban growth and shrinkage-A modeling approach assessing ecosystem service trade-offs. Ecol. Indic. 2014, 42, 73-94. [CrossRef]

97. Qiao, Z.; Tian, G.; Zhang, L.; Xu, X. Influences of Urban Expansion on Urban Heat Island in Beijing during 1989-2010. Adv. Meteorol. 2014, 2014, 187169. [CrossRef]

98. Turner, K.G.; Anderson, S.; Gonzales-Chang, M.; Costanza, R.; Courville, S.; Dalgaard, T.; Dominati, E.; Kubiszewski, I.; Ogilvy, S.; Porfirio, L.; et al. A review of methods, data, and models to assess changes in the value of ecosystem services from land degradation and restoration. Ecol. Model. 2016, 319, 190-207. [CrossRef]

99. Singh, R.; Kalota, D. Urban Sprawl and Its Impact on Generation of Urban Heat Island: A Case Study of Ludhiana City. J. Indian Soc. Remote Sens. 2019, 47, 1567-1576. [CrossRef]

100. Frumkin, H. Urban Sprawl and Public Health. Public Health Rep. 2002, 117, 211-217. [CrossRef]

101. Furuseth, O.J.; Pierce, J.T. Agricultural Land in an Urban Society; Association of American Geographers: Washington, DC, USA, 1982.

102. Chelli, F.M.; Ciommi, M.; Emili, A.; Gigliarano, C.; Taralli, S. Assessing the Equitable and Sustainable Well-Being of the Italian Provinces. Int. J. Uncertain. Fuzziness Knowl. Based Syst. 2016, 24, 39-62. [CrossRef]

103. Barlow, S.A.; Munn, I.A.; Cleaves, D.A.; Evans, D.L. The effects of urban sprawl on timber harvest. J. For. 1998, 96, 10-14.

104. Newman, P.; Kenworthy, J. Cities and Automobile Dependence: An International Sourcebook; Gower: London, UK, 1989.

105. Güneralp, B.; Zhou, Y.; Ürge-Vorsatz, D.; Gupta, M.; Patel, S.Y.P.L.; Fragkias, M.; Li, X.; Karen, C. Scenarios of urban density and energy use by 2050. Proc. Natl. Acad. Sci. USA 2017, 114, 8945-8950. [CrossRef]

106. Legget, R.F. Cities and Geology; McGraw-Hill: New York, NY, USA, 1973.

107. Alphan, H. Land use change and urbanisation of Adana, Turkey. Land Degrad. Dev. 2003, 14, 575-586. [CrossRef]

108. Newman, P.; Kenworthy, J. Sustainability and Cities: Overcoming Automobiledependence; Island Press: Washington, DC, USA, 1999.

109. Aguilar, A.G. Peri-urbanization, illegal settlements and environmental impact in Mexico City. Cities 2008, 25, 133-145. [CrossRef]

110. Barbero-Sierra, C.; Marques, M.J.; Ruíz-Pérez, M. The case of urban sprawl in Spain as an active and irreversible driving force for desertification. J. Arid Environ. 2013, 90, 95-102. [CrossRef]

111. Brouwer, F.B.; Thomas, A.J.; Chadwick, M.J. Land Use Changes in Europe. Processes of Change, Environmental Transformations and Future Patterns; Kluwer: Dordrecht, The Netherlands, 1991.

112. Rico-Amoros, A.M.; Olcina-Cantos, J.; Saurí, D. Tourist land use patterns and water demand: Evidence from the Western Mediterranean. Land Use Policy 2009, 26, 493-501. [CrossRef]

113. Balchin, P. Housing Policy in Europe; Routledge: London, UK; New York, NY, USA, 1996.

114. Camagni, R.; Capello, R.; Nijkamp, P. Toward Sustainable City Policy: An Economy-Environment-Technology Nexus. Ecol. Econ. 1998, 24, 103-118. [CrossRef] 
115. Burchell, R.W.; Downs, A.; McCann, B.; Mukherji, S. Sprawl Costs—Economic Impacts of Unchecked Development; Island Press: Washington, DC, USA, 2005.

116. Cuadrado-Ciuraneta, S.; Durà-Guimerà, A.; Salvati, L. Not only tourism: Unravelling suburbanization, second-home expansion and "rural" sprawl in Catalonia, Spain. Urban Geogr. 2017, 38, 66-89. [CrossRef]

117. The Paris Agreement. Available online: https://unfccc.int/process-and-meetings/the-paris-agreement/the-paris-agreement (accessed on 13 January 2021). 